\title{
Improving farm productivity through the reduction of managerial and technology gaps among farmers in Rwanda
}

\author{
Jules Ngango * (10 and Seungjee Hong
}

\begin{abstract}
Background: Rwanda and most parts of sub-Saharan Africa face severe challenges of increasing maize productivity, which has direct consequences on food security. Due to these challenges, policy-makers have paid particular attention to finding the cost-effective strategies of boosting maize production. In an effort to increase productivity, the literature suggests that the adoption of yield-enhancing technologies and production efficiency should be given priority. The objective of this study is to examine and compare the technical efficiency and technological gaps of maize farms that grow different seed varieties in Rwanda.

Methods: The data used in this study were obtained from a survey of 360 household farmers conducted in the Eastern Province of Rwanda during the 2018-2019 cropping season. The study applies the stochastic meta-frontier production function approach to estimate the technical efficiency and technological gaps of maize farms operating under heterogeneous production technologies.
\end{abstract}

Results: Results indicate that there are differences in technical efficiency measures among the three groups of farmers (i.e., adopters of hybrids, open-pollinated varieties, and local maize varieties). In particular, we find that on average, farms growing hybrid maize varieties appear to have higher values of technical efficiency, technology gap ratio, and meta-frontier technical efficiency than farms growing OPVs and local maize varieties. Thus, the analysis shows that there are significant technological and managerial performance gaps among farmers.

Conclusions: From a policy perspective, the results of this study suggest the development of policy measures that may reduce the managerial and technological gaps existing among farmers to improve productivity and food security. Based on the results of this study, one of the crucial avenues to close this gap would be to improve access to improved agricultural technologies such as certified hybrid seeds. Additionally, policies aiming to enhance technical efficiency and productivity should focus on expanding the delivery of extension services and strengthening the technical assistance provided to farmers' cooperatives.

Keywords: Technical efficiency, Technology gap ratio, Stochastic meta-frontier, Maize production, Maize varieties, Rwanda

*Correspondence: ngajules2@gmail.com Department of Agricultural Economics, Chungnam National University, Daejeon 34134, South Korea

\begin{abstract}
Background
Agricultural productivity growth is a critical component of the economic development of many African countries [1]. Particularly in sub-Saharan Africa (SSA), government policy strategies are aimed at improving the agricultural productivity which could lead to improved household food security and increased farm income [2].
\end{abstract} adaptation, distribution and reproduction in any medium or format, as long as you give appropriate credit to the original author(s) and the source, provide a link to the Creative Commons licence, and indicate if changes were made. The images or other third party material in this article are included in the article's Creative Commons licence, unless indicated otherwise in a credit line to the material. If material is not included in the article's Creative Commons licence and your intended use is not permitted by statutory regulation or exceeds the permitted use, you will need to obtain permission directly from the copyright holder. To view a copy of this licence, visit http://creativecommons.org/licenses/by/4.0/. The Creative Commons Public Domain Dedication waiver (http://creativecommons.org/publicdomain/zero/1.0/) applies to the data made available in this article, unless otherwise stated in a credit line to the data. 
Indeed, given the rapid population growth and poverty in SSA, to achieve the objective of household and national food security requires a considerable improvement in agricultural productivity through the adoption of yieldenhancing technologies. Meanwhile, empirical literature suggests that the rise in the levels of technical efficiency (TE) also provides an intuitive solution to the increased agricultural productivity growth [1-6]. As noted by Onumah et al. [7], the improvement in TE is the best and cost-effective option to increase agricultural productivity for farmers who operate below the efficient frontier.

Given that ensuring food security in developing countries is the main goal [8], the literature identified the improvements in agricultural productivity (i.e., stimulated by government investment in rural infrastructure, agricultural research and extension, irrigation, and appropriate price incentives) as the major elements contributing directly to the economic growth, poverty alleviation, and stability [9]. As noted by Timmer [9], each of these three elements is in turn a primary input into food security at both the macro and micro levels. In general, the concept of food security is defined as a situation whereby, "all individuals at all times, have physical, social and economic access to sufficient, safe and nutritious food to meet their dietary needs for an active and healthy life" [10]. This concept of food security emphasizes on three dimensions, namely, availability, accessibility, and utilization of food [10]. In particular, the availability is achieved if adequate food is ready to have at people's disposal (through domestic production or imports), while the accessibility is ensured if all individuals have sufficient resources to obtain appropriate food (through production, purchase or donation) for a nutritious diet [9, 10]. Consequently, policy interventions may concentrate on improving the technical efficiency and productivity to ensure food availability and access dimensions of food security.

In Rwanda, agriculture production employs about 75\% of the labor force [11, 12]. Mainly, crop production contributes about $69 \%$ of total national agricultural output in Rwanda, with maize accounting for more than 50\% [11]. Meanwhile, [13] highlighted several factors that can explain the predominance of maize in Rwanda relative to other crops. Those factors include its suitability to the Rwandan weather and soil type, and the prevalence of maize flour processing facilities influenced the adaptation of many Rwandans to maize diet $[13,14]$. In addition, the crop intensification program (CIP), which was introduced by the government of Rwanda in 2007, was aimed at promoting maize crop [15]. The input subsidy program and the small-scale irrigation technology development are the other government interventions that are considered to raise maize production and supply in
Rwanda. Hence, there is a need to investigate the productive efficiency of maize farms to provide useful policy implications with regards to the improvement of maize productivity.

The literature on TE of maize production in Rwanda is limited. Moreover, the few studies [16-18] that have attempted to analyze the TE of maize, have assumed homogeneity in production technology across all farms and the estimation of TE used a single production frontier. However, it is necessary to account for heterogeneity in production technology that might exist across farms operating in different production systems $[6,19,20]$. The objective of this study is to examine and compare the TE of maize farms that grow different seed varieties using the stochastic meta-frontier (SMF) model developed by Huang et al. [21]. In particular, maize varieties adopted by farmers in Rwanda are classified into three categories: hybrids, open-pollinated varieties (OPVs), and local varieties. Thus, the SMF approach allows us to generate a conventional technology that enables a direct comparison of TE across the three groups.

To the best of our knowledge, the literature does not comprise any study that has attempted to assess the relative TE of farms operating under different production technologies in Rwanda. Our study contributes to the existing literature by demonstrating the application of a meta-frontier approach to the estimation of TE levels across heterogeneous groups. Indeed, the meta-frontier methodology allows us to address the issue of comparing group-specific frontiers with the meta-frontier [22]. Additionally, this method can address the technological gap (i.e., the difference in the production frontier) that might exist across different production systems [20].

The remainder of this paper is organized in the following way. The second section presents an overview of the use of maize varieties and productivity growth in Rwanda. The third section provides the research methodology, followed by a description of the data and variables in the fourth section. The fifth section provides a discussion of empirical results. Finally, conclusions and policy implications are highlighted in "Conclusion and policy implications" section.

\section{A brief description of the Rwandan agrarian structure}

The Rwandan economy rely heavily on the agriculture sector which is still subsistence farming [23]. In Rwanda, more than $70 \%$ of the population are employed in agriculture [23]. Rwanda has a favorable altitude, climate and rainfall conditions for agriculture. Though, the hilly topography with steep slopes has been conducive to depleting soils through rapid runoff of surface water and soil erosion [24]. Rwanda has the highest population 


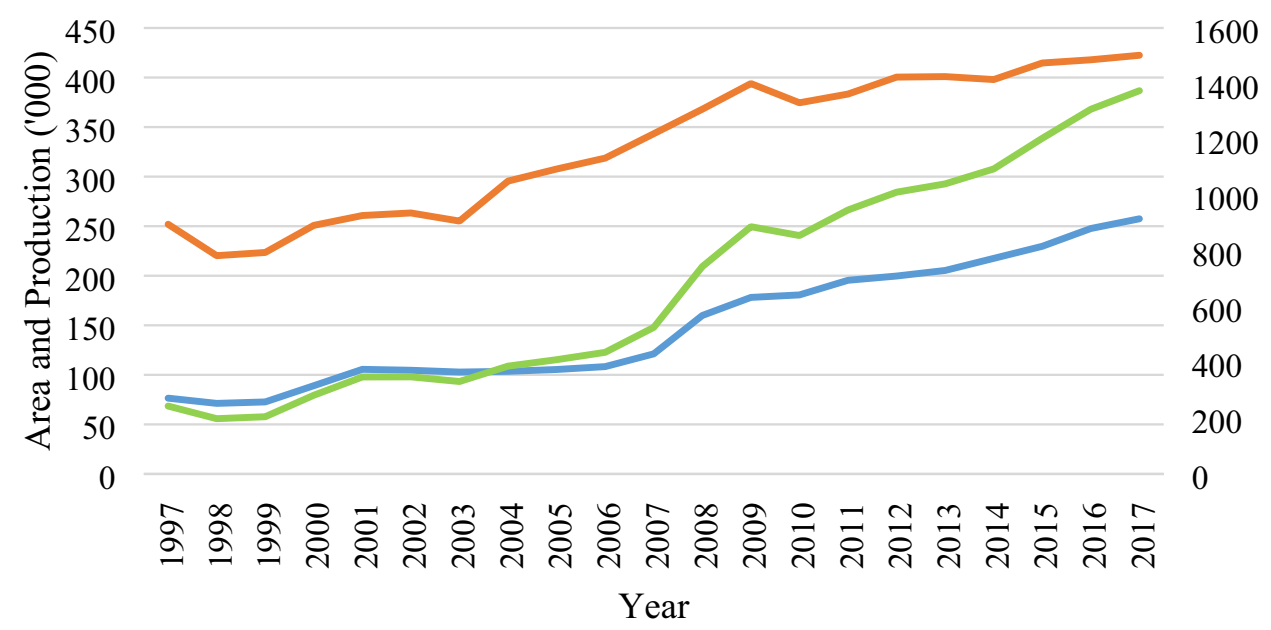

Fig. 1 Annual maize production, area cultivated, and yields from 1997 to 2017

density as compared to the rest of African countries. Rwanda also has the high population growth rates, a small average land holdings which is approximately 0.75 hectares per household, and a high incidence of landlessness [23, 25]. Recently, the issue of small-scale farm sizes, land fragmentation, and low crop productivity in Rwanda remains a priority to policy-makers, research institutions, and nongovernment organizations [26]. Additionally, over the past decades, farmers in Rwanda practiced intercropping system of agriculture and cultivated several small plots in different parts of the landscape [23]. Typically, about $80 \%$ of the Rwandan population live in rural areas and around $36 \%$ of the households own an average farm size of roughly 0.11 ha (i.e., $6 \%$ of the farm lands). $30 \%$ of the households own an average farm size of roughly 0.6 ha (i.e., $24 \%$ of the farm lands), while $24 \%$ of households own an average farm size of about 2 ha (i.e., $70 \%$ of the farm lands), in addition, approximately $10 \%$ of the households are landless [27]. The national average holding of 0.76 ha is generally divided over $4-5$ small plots, often in multiple locations [27].

In an attempt to achieve food security, the Rwandan government has adopted the land consolidation program for the purpose of reallocating fragmented small-scale farm plots to form large-scale parcels for more rational land holding [28]. Furthermore, the key dimension of Rwanda's agrarian policy is to intensify agriculture and transform the subsistence farming into a modern and commercial agriculture [23]. This policy includes the formalization of land tenure, the promotion of intensified production of specified marketable crops through use of modern inputs, and regional specialization where regions concentrate on specific crop combinations depending upon the agro-climate in that region [23]. There is also a need to foster the capacity building of farmers to ensure the adoption of fertilizer and improved seeds. This task is undertaken by nine extension service providers who assign a proximity extension agent to every 500 ha in land use consolidated areas [13].

\section{Overview of maize varieties and productivity growth in Rwanda}

The importance of maize in food security and economic development of Rwanda and many SSA has prompted researchers to conduct various studies on the efficiency and productivity of this crop. The government of Rwanda and its partners have made efforts to enhance maize production. Figure 1 indicates that the total maize production has tremendously increased in the past two decades. The sources of maize production growth in Rwanda is mainly due to the expansion of cultivated area [13]. The CIP introduced in 2007 by the Ministry of Agriculture and Animal Resources (MINAGRI) also contributed to the provision of extension services, land use consolidation, input subsidies, and development of small-scale irrigation technologies [15]. At the national level, CIP conducted pieces of training on the use of fertilizers and improved varieties which resulted in the increase of crop productivity [13]. However, the adoption rate is still meager due to the high cost and lack of awareness of the benefits of using recommended fertilizer rates and hybrid cultivars [15]. In particular, the use of relatively low quality of seeds and inappropriate timing of sowing has been 
broadly cited as the primary source of inefficiency among farmers in most developing countries [29].

With regards to the improved maize varieties (IMVs) used in Rwanda, there are two broad categories of IMVs, including hybrids and OPVs. Hybrid seed variety production involves the crossing of two or inbred lines, and when the hybrid seed is replanted, it cannot be as productive as the original seed [30]. The major hybrid maize varieties disseminated in Rwanda include PAN 4M21, PAN 53, PAN 67, SC 403, SC 513, SC 529, WH 505, WH 507, WH 403, H 513, RHM 104, RHM 1407, RHM 1402, H 628, H 629, PAN 691, SC 719, and SC 637 [11]. On the other hand, OPVs are populations that breeders have selected for specific set traits (i.e., no inbred lines or parents), and they can usually be replanted up to three years without decreasing the yield [31]. The major OPVs disseminated in Rwanda include ZM 607, M 101, M 103, Pool 9A, and Pool 8A, which are known to be adapted to low soil moisture and nutrient conditions.

About the comparison of physiological characteristics of the two categories of IMVs, a large body of empirical evidence demonstrated that OPVs are generally lower yielding than hybrid maize varieties due to the effect of heterosis (i.e., hybrid vigor or outbreeding enhancement) [32]. Besides, maize hybrids provide higher quality (e.g., uniform grain color and size) and offer superior disease resistance than OPVs. However, hybrid maize varieties are expensive for resource-poor farmers [32]. From both agronomic and farmers' socio-economic context, another disadvantage of using hybrid seeds is the difficulty to save seeds and produce another generation, because if hybrids are replanted in the next season, they cannot be as productive as the original seeds [30]. In addition, some farmers contend that hybrids are less tasty [32]. Indeed, all those dimensions may influence farmers' decisions to adopt hybrids. In Rwanda, despite the government efforts to subsidize improved seeds, farmers and their families are still engaged in the practices of saving indigenous seeds for the next planting season.

\section{Materials and methods}

\section{Conceptual framework}

The stochastic frontier analysis (SFA) has been extensively used in the agriculture sector to measure the TE [29]. The SFA was preferred in many empirical studies due to its ability to manage the effect of data noise and inefficiency [33]. ${ }^{1}$ However, the limitation of the original SFA developed by Aigner et al. [34] and Meeusen, van Den Broeck [35] is the failure to address the issue of

\footnotetext{
${ }^{1}$ The data noise can be caused by random factors such as adverse weather conditions and measurement errors.
}

technological heterogeneity [33]. To address this limitation, economics literature has suggested a meta-frontier framework that allows the estimation and comparison of TEs of farms operating under different production technologies [36]. In this study, the production technology referred to consist of seed technologies.

The concept of meta-frontier was initially proposed by Hayami [37]. In this concept, he assumed that farmers have potential access to different production technologies, and various factors determine the adoption of such technologies. Later, Hayami, Ruttan [38] made a further assumption that the same production function can describe technical possibilities available to farmers classified into different groups. Battese, Rao [39] extended the meta-frontier approach and introduced a SMF production function that allows the estimation of TEs of firms classified into different groups. This method was further extended by Battese et al. [40] and O'Donnell et al. [41] to be a two-stage procedure for the estimation of metafrontier. The first stage of this approach uses the SFA model to estimate the individual frontiers for each group. In the second stage, a mathematical programming technique, such as Data Envelopment Analysis (DEA) is used to estimate the meta-frontier by combining the groupspecific stochastic production functions [22]. However, a potential limitation of this method lies in the estimation of the second stage, in which the meta-frontier estimators lack desirable statistical properties due to the deterministic nature of mathematical programming [22]. In addition, mathematical programming methods cannot separate the idiosyncratic shocks from the model; hence, the estimation results are susceptible to random noise [2, 22].

Due to the limitation of the second stage in the SMF developed by Battese et al. [40] and O'Donnell et al. [41], Huang et al. [21] proposed a SMF model that uses SFA to estimate meta-frontier parameters in the second stage rather than mathematical programming methods. Huang et al. [21] contend that the SFA approach can address the issue of statistical noise and provides desirable statistical properties of the parameters in the estimation of metafrontier. Moreover, the SMF approach of Huang et al. [21] uses the maximum likelihood estimation (MLE), which allows the computation of statistical inferences without the need to depend on simulations or bootstrapping methods [22]. Huang et al. [21] assert that the SMF approach can estimate the technology gap ratios (TGRs) directly.

Since the SMF approach provides appropriate statistical properties for inference and can isolate TGRs from random shocks which allows TGR to be expressed as a function of exogenous environmental variables [2], we 
use the SMF approach developed by Huang et al. [21] in this study.

\section{Stochastic meta-frontier specification}

Following Huang et al. [21], the SMF model used to estimate the TE of farms adopting different technologies, is specified in a two-step procedure. In the first step, individual group frontiers are estimated, while in the second step, stochastic frontier methods are applied to estimate the meta-frontier production function. The stochastic production function for the $i$ th farmer is expressed as

$$
Y_{j i}=f^{j}\left(X_{j i} ; \beta^{j}\right) e^{V_{j i}-U_{j i}}, \quad i=1,2, \ldots, N_{j} ; j=1,2, \ldots, J
$$

where $Y_{j i}$ represents the output of the $i$ th farmer in the $j$ th group; $X_{j i}$ represents a vector of inputs of the $i$ th farmer in the $j$ th group; $\beta^{j}$ is a vector of unknown parameters to be estimated for the $j$ th group. Moreover, $V_{j i}$ is a random error component that represents the statistical noise and is assumed to be identically and independently distributed with mean as 0 and constant variance as $\left[V_{j i} \sim N\left(0, \sigma_{v}^{j 2}\right)\right]$. The non-negative random errors $U_{j i}$ represent the technical inefficiency of the $i^{\text {th }}$ farmer in the $j^{\text {th }}$ group. $U_{j i}$ follows a truncated normal distribution and is defined as $U_{j i} \sim N^{+}\left(\delta_{j} Z_{j i}, \sigma^{j 2}\right)$, where $Z_{j i}$ represents a vector of exogenous variables associated with the technical inefficiency of the $i$ th farmer in the $j$ th group; $\delta_{j}$ is a vector of unknown parameters to be estimated.

The TE of the $i$ th farmer in $j$ th group is specified as the ratio of actual output to the maximum output possible:

$$
T E_{i}^{j}=\frac{Y_{j i}}{f^{j}\left(X_{j i}\right) e^{V_{j i}}}=e^{-U_{j i}} .
$$

As suggested by Huang et al. [21], the meta-frontier production function $f^{M}\left(X_{j i}\right)$ that envelops the three group-specific frontiers $f^{j}\left(X_{j i}\right)$ is defined by the following relationship:

$$
f^{j}\left(X_{j i}\right)=f^{M}\left(X_{j i}\right) e^{-U_{j i}^{M}}, \forall j, i
$$

where $U_{j i}^{M} \geq 0$, suggesting that $f^{M}(\bullet) \geq f^{j}(\bullet)$ and the TGR which is computed as the ratio of the frontier production function for the $j$ th group relative to the meta-frontier:

$$
\operatorname{TGR}_{i}^{j}=\frac{f^{j}\left(X_{j i}\right)}{f^{M}\left(X_{j i}\right)}=e^{-U_{j i}^{M}} \leq 1
$$

Following Huang et al. [21], for given levels of inputs, the observed output of the $i$ th farmer with respect to the meta-frontier function, adjusted for the corresponding random error is defined as:

$$
\frac{Y_{j i}}{f^{M}\left(X_{j i}\right)}=T G R_{i}^{j} \times T E_{i}^{j} \times e^{V_{j i}} .
$$

In the above, it is important to note that though $T G R_{i}^{j}$ and $T E_{i}^{j}$ are bounded between 0 and 1, the meta-frontier function does not certainly envelope all farmers' observed outputs due to random noise [22]. Indeed, the unrestricted ratio given in Eq. (5) differentiates the use of the SFA method with mathematical programming to model the meta-frontier. Accordingly, given that the random noise component is obtained from the SFA, the TE of the $i$ th farmer with respect to the meta-frontier, is expressed as:

$$
M T E_{j i}=\frac{Y_{j i}}{f^{M}\left(X_{j i}\right) e^{V_{j i}}}=T G R_{i}^{j} \times T E_{i}^{j} .
$$

The meta-frontier production function in Eq. (3) was specified using mathematical programming methods proposed by O'Donnell et al. [41]. However, due to the limitations of this approach highlighted earlier, we can reformulate Eq. (3) using the methodology proposed by Huang et al. [21]:

$$
\operatorname{lnf}^{\mathrm{j}}\left(\mathrm{X}_{\mathrm{ji}}\right)=\operatorname{lnf}^{\mathrm{M}}\left(\mathrm{X}_{\mathrm{ji}}\right)-\mathrm{U}_{\mathrm{ji}}^{\mathrm{M}}
$$

Here, the individual group frontier $f^{j}\left(X_{j i}\right)$ is unobservable. Still its values can be estimated from the first step, and as the fitted values of $f^{j}\left(X_{j i}\right)$ differ from the actual frontier, Eq. (7) can be redefined as:

$$
\operatorname{lnf}^{\mathrm{j}}\left(\mathrm{X}_{\mathrm{ji}}\right)=\operatorname{lnf}^{\mathrm{M}}\left(\mathrm{X}_{\mathrm{ji}}\right)-\mathrm{U}_{\mathrm{ji}}^{\mathrm{M}}+\mathrm{V}_{\mathrm{ji}}^{\mathrm{M}},
$$

where $V_{j i}^{M}$ denotes a symmetric noise that represents the deviation between the fitted values $\widehat{f}^{j}\left(X_{j i}\right)$ and the true frontier $f^{j}\left(X_{j i}\right)$. That is,

$$
V_{j i}^{M}=\operatorname{lnf}^{\mathrm{j}}\left(\mathrm{X}_{\mathrm{ji}}\right)-\mathrm{f}^{\mathrm{j}}\left(\mathrm{X}_{\mathrm{ji}}\right),
$$

where the error term $V_{j i}^{M}$ is typically distributed as $N\left(0, \sigma_{v}^{M 2}\right)$ while the non-negative technology gap component $U_{j i}^{M} \geq 0$ is assumed to be distributed as truncated normal, i.e., $U_{j i}^{M} \sim N^{+}\left(\mu^{M}\left(Z_{j i}\right), \sigma^{M 2}\right)$, where $Z_{j i}$ represents the production environment variable vector.

Equation (8) holds the resemblance with the conventional stochastic frontier model, and in consequence, $\operatorname{lnf}^{\mathrm{M}}\left(\mathrm{X}_{\mathrm{ji}}\right)+\mathrm{V}_{\mathrm{ji}}^{\mathrm{M}}$ is referred to as the SMF model. Usually, this model is performed using the maximum likelihood estimation, and the parameter estimates are consistent and asymptotically normally distributed [22]. The SMF model allows for the estimated group-specific frontier to be larger than or equal to the meta-frontier due to statistical noise. However, the meta-frontier should be larger than or equal to the group-specific frontier, i.e., 
$f^{M}\left(X_{j i}\right) \geq f^{j}\left(X_{j i}\right)$ [22]. Therefore, the estimated TGR is calculated as:

$$
T \widehat{G} R_{i}^{j}=\widehat{E}\left(e^{-U_{j i}^{M}} \mid \widehat{\varepsilon}_{j i}^{M}\right) \leq 1,
$$

where $\widehat{\varepsilon}_{j i}^{M}=\ln \widehat{f}^{\mathrm{j}}\left(\mathrm{X}_{\mathrm{ji}}\right)-\ln \widehat{\mathrm{f}}^{\mathrm{M}}\left(\mathrm{X}_{\mathrm{ji}}\right)$ is the estimated composite residual of Eq. (8).

\section{Functional form specification}

Cobb-Douglas and translog functional forms are the most commonly applied in efficiency analysis. In this study, we use the Cobb-Douglas functional form to estimate both group-specific stochastic frontier and stochastic meta-frontier parameters. The choice of Cobb-Douglas is based on the results of the likelihood ratio test. The value of the likelihood ratio test statistic is about 6.21 leading to the acceptance of the null hypothesis stating that Cobb-Douglas functional form is the appropriate representation of the data relative to the translog functional form. ${ }^{2}$ The Cobb-Douglas functional form is specified as follows:

$$
\ln \left(\mathrm{Y}_{\mathrm{i}}\right)=\beta_{0}+\sum_{\mathrm{j}=1}^{4} \beta_{\mathrm{j}} \ln \mathrm{X}_{\mathrm{ji}}+\left(\mathrm{v}_{\mathrm{i}}-\mathrm{u}_{\mathrm{i}}\right)
$$

where $Y_{i}$ represents the maize output of the $i$ th farmer; $X_{j i}$ represents the quantity of the $j$ th input used by the $i$ th farmer; $\beta$ denotes a vector of unknown parameters to be estimated; $v_{i}$ is the random error term and $u_{i}$ is the nonnegative inefficient term. Following Battese, Coelli [43], the inefficiency effects model can be written as:

$$
\mu_{i}=\delta_{0}+\sum_{j=1}^{10} \delta_{j} Z_{j i},
$$

where $Z_{j i}$ denotes a vector of farmer-specific variables that might influence the TE.

\section{Data and variables}

The data used in this study are cross-sectional data from a household survey conducted in the Eastern Province of Rwanda from July to August 2019. A representative sample of this study consists of 360 household farmers that were randomly selected from three districts, namely Bugesera, Kirehe, and Nyagatare districts of the Eastern Province of Rwanda. This sample was drawn using a multistage sampling technique. First, in consultation with

\footnotetext{
${ }^{2}$ Although the Cobb-Douglas imposes restrictions on partial production elasticities and returns to scale to take the same value across all observations, it provides satisfactory parameter estimates than the translog. It is also more consistent with the production economic theory. Besides, inputs and interaction terms in a translog functional form are likely to have the problem of multicollinearity [42].
}

the MINAGRI, three districts were purposively selected based on their intensive maize production. In the second stage, four administrative sectors were randomly selected from each district. Finally, a simple random sampling technique was used to select a total of 360 maize farmers. Respondents were interviewed using a structured questionnaire by trained and experienced research assistants. The survey collected detailed information on maize production output, and inputs used in the production process during the 2018-2019 crop season. Besides, information on socio-economic characteristics of households, institutional, and farm-specific characteristics were also collected. For the purpose of this study, each farmer was asked about the type of maize seed variety planted during the 2018-2019 cropping season to classify farmers into three groups (i.e., adopters of hybrids, OPVs, and local seeds).

All variables used in the analysis are presented in Table 1 . As regards to the inputs used in maize production, four variables are included in our model: land, labor, fertilizer, and seeds. The land input is measured as the total farm size in hectares (ha) planted with maize during the 2018-2019 crop season. Labor input (i.e., hired and family labor) used to perform all farm operations during the 2018-2019 crop season is measured in person-days per ha. Particularly in SSA countries, the labor force consists of men, women, and children. Hence, following Khataza et al. [45], labor is defined in terms of adult equivalent units using the following conversion factors: one adult male (at least 15 years of age, working on a full day-basis) represents one person-day. While an adult female working on a full day-basis represents 0.8 person-days, and one child (5-14 years) working for a full day represents 0.5 person-days $[45,46]$. Fertilizer input is measured as the total quantity of di-ammonium phosphate (DAP) and urea in kilograms (kg) per ha applied on the farm during the 2018-2019 crop season. Seed input is expressed as the quantity in $\mathrm{kg}$ per ha of maize seeds used in farm production during the 2018-2019 cropping season.

The household, institutional, and farm characteristics used in the analysis as the determinants of technical inefficiency are also presented in Table 1. Household demographic variables such as age, education, household size, and gender may influence the TE. For instance, higher education levels are expected to improve farmers' managerial performance, which could also enhance their TE's level [46, 47]. A dummy variable for cooperative membership is included to assess the effect of cooperatives on TE. Based on the empirical evidence from previous studies [42, 48-50], we expect the participation in farmers' cooperatives to have a positive effect on TE. Other institutional 
Table 1 Description of variables used in the analysis

\begin{tabular}{ll}
\hline Variables & Definition \\
\hline Output & Total maize production per ha (kg per ha) \\
Land & Total land size planted with maize crop (ha) \\
Labor & Labor input including both hired and family labor (person-days per ha) \\
Fertilizer & Quantity of fertilizer used (kg per ha) \\
Seed & Amount of seeds used (kg per ha) \\
Age & Age of household head (years) \\
Gender & Dummy variable equal to 1 if the household head is male, 0 otherwise \\
Education & Number of years of formal education \\
Household size & Total household size (number of persons) \\
Coop. membership & Dummy variable for cooperative membership equal to 1 if a farmer is a member of the \\
Extension services & cooperative, 0 otherwise \\
Credit access & The frequency of extension visits (number per year) \\
Off-farm Income & Dummy variable for credit access equal to 1 if a farmer has access to credit, 0 otherwise \\
Land tenure & Dummy variable equal to 1 if a farmer has other sources of income off-farm, 0 otherwise \\
Slope & Dummy variable for land tenure equal to 1 if a farmer owns the land, 0 if rented \\
Livestock ownership & Dummy variable for slope equal to 1 if the land is characterized by steep slopes, 0 otherwise
\end{tabular}

TLU across various categories of livestock are computed as; 0.7 for cows; 0.45 for Heifers; 0.1 for goats; 0.1 for sheep; 0.01 for chicken; 0.2 for Pigs [ 44 ]

Table 2 Descriptive statistics of the data

\begin{tabular}{|c|c|c|c|c|c|c|c|c|}
\hline \multirow[t]{2}{*}{ Variable } & \multicolumn{2}{|c|}{ Local varieties } & \multicolumn{2}{|l|}{ OPVs } & \multicolumn{2}{|l|}{ Hybrids } & \multicolumn{2}{|c|}{ Pooled sample } \\
\hline & Mean & Std. dev & Mean & Std. dev & Mean & Std. dev & Mean & Std. dev \\
\hline Yield & 1767.87 & 219.56 & 1985.99 & 230.48 & 2307.52 & 266.12 & 1990.69 & 293.56 \\
\hline Land & 1.17 & 0.63 & 1.75 & 0.85 & 2.23 & 0.99 & 1.69 & 0.90 \\
\hline Labor & 21.39 & 5.01 & 23.12 & 4.11 & 26.13 & 4.27 & 23.24 & 4.63 \\
\hline Fertilizer & 104.67 & 32.19 & 125.52 & 28.19 & 147.74 & 35.98 & 124.38 & 33.82 \\
\hline Seed & 29.47 & 7.47 & 31.49 & 6.47 & 34.50 & 8.33 & 31.54 & 7.27 \\
\hline Age & 44.13 & 12.03 & 46.99 & 10.17 & 50.46 & 8.78 & 46.91 & 10.61 \\
\hline Gender & 0.57 & 0.49 & 0.70 & 0.46 & 0.82 & 0.39 & 0.69 & 0.46 \\
\hline Education & 4.23 & 1.78 & 5.77 & 2.12 & 8.09 & 2.85 & 5.81 & 2.53 \\
\hline Household size & 5.94 & 1.72 & 6.83 & 1.57 & 7.22 & 1.42 & 6.68 & 1.64 \\
\hline Coop. membership & 0.27 & 0.45 & 0.55 & 0.50 & 0.67 & 0.47 & 0.50 & 0.50 \\
\hline Extension services & 26.76 & 6.97 & 31.02 & 7.22 & 35.81 & 8.02 & 30.83 & 7.88 \\
\hline Land tenure & 0.49 & 0.50 & 0.48 & 0.50 & 0.61 & 0.49 & 0.51 & 0.50 \\
\hline Credit access & 0.30 & 0.46 & 0.57 & 0.49 & 0.52 & 0.50 & 0.49 & 0.50 \\
\hline Off-farm income & 0.35 & 0.48 & 0.36 & 0.48 & 0.46 & 0.50 & 0.37 & 0.48 \\
\hline Slope & 0.71 & 0.45 & 0.50 & 0.50 & 0.21 & 0.41 & 0.50 & 0.50 \\
\hline Livestock ownership & 0.62 & 0.66 & 1.36 & 0.97 & 2.39 & 1.27 & 1.37 & 1.13 \\
\hline No. of observations & 91 & & 202 & & 67 & & 360 & \\
\hline
\end{tabular}

factors, such as extension services and access to credit, are considered essential determinants of farm TE, and they are both expected to be positively correlated with TE. The variable slope is expressed as a dummy variable equal to one if the farm is located on a steep hill and zero otherwise. Typically, the slope is expected to be negatively correlated with the TE due to the evidence that steep slopes tend to face problems related to irrigation development, mechanization, and soil erosion [46]. The remaining explanatory variables are land tenure, off-farm income, and livestock ownership. 


\section{Summary statistics}

Table 2 illustrates the mean values and standard deviations of all variables used in this study. The summary statistics given in Table 2 indicate that there are considerable differences in output, inputs, and household characteristics among the three groups of farmers using hybrid, OPVs, and local maize varieties. Farms growing hybrid maize varieties recorded the highest average maize output per hectare $(2307.52 \mathrm{~kg} / \mathrm{ha})$, while the farms growing local varieties recorded the lowest average maize output per hectare $(1767.87 \mathrm{~kg} / \mathrm{ha})$. With regards to the farm inputs, on average, farms growing hybrid maize varieties used a higher amount of fertilizers $(147.74 \mathrm{~kg} / \mathrm{ha}$ ) relative to farms growing OPVs $(125.52 \mathrm{~kg} / \mathrm{ha})$ and local maize varieties $(104.67 \mathrm{~kg} / \mathrm{ha})$. Similarly, on average, farms growing hybrid maize varieties used a higher amount of seeds $(34.50 \mathrm{~kg} / \mathrm{ha})$ compared to farms growing OPVs (31.49 kg/ha) and local maize varieties $(29.47 \mathrm{~kg} / \mathrm{ha})$. In terms of the amount of labor employed, farms growing hybrid maize varieties engaged labor more intensively than farms growing OPVs and local maize varieties. In addition, the land allocated to maize production is about $2.23,1.75$, and 1.17 hectares for farms growing hybrid, OPVs, and local maize varieties, respectively.

In terms of socio-economic characteristics of farmers, Table 2 indicates that, on average, the age of farmers in the sample is approximately 47 years old, and the level of formal education is around 6 years of primary school. Table 2 also indicates that, on average, $69 \%$ of households in the sample are male-headed. In particular, farmers who planted hybrid maize varieties appear to be older and more educated than farmers who planted OPVs and local maize varieties. Moreover, farmers who planted hybrid maize varieties appear to have better access to extension services and credit facilities than farmers who planted OPVs and local maize varieties. The proportion of farmers who are members of agricultural cooperatives is higher for those who planted hybrid maize varieties. With regards to livestock ownership, producers who planted hybrid maize varieties own more livestock than the producers who planted OPVs and local maize varieties.

\section{Empirical results and discussion}

In this section, we present the specification tests and the maximum likelihood estimates of the group-specific stochastic production frontier model. The parameter estimates of the stochastic meta-frontier production function are also presented in this section. Finally, summary statistics of TE scores by individual group frontier; TE scores from the meta-frontier; and the TGR for maize farmers are reported and discussed.

\section{Model specification tests}

The generalized likelihood ratio test is used to specify the adequacy of a functional form used and check the presence of technical inefficiency. Moreover, the likelihood ratio test is used to evaluate the relevance of estimating the meta-frontier model. The likelihood ratio test statistic, which is computed as, $\lambda=-2\left\{\ln \left[\operatorname{Likelihood}\left(\mathrm{H}_{0}\right)\right]-\ln \left[\operatorname{Likelihood}\left(\mathrm{H}_{1}\right)\right]\right\} \quad$ has a chi-squared $\left(\chi^{2}\right)$ distribution with the degrees of freedom equal to the difference between the number of parameters estimated under alternative hypothesis and the null hypothesis [51].

The first test involves a null hypothesis, which assumes that there is no technical inefficiency in maize production for all three individual groups of farmers. This null hypothesis is strongly rejected at the $1 \%$ level of significance for all the three models (see Table 3), confirming the presence of technical inefficiency in maize production for all groups of farmers (i.e., adopters of hybrid, OPVs, and local maize varieties). The null hypothesis of the second test assumes that the explanatory variables included in the inefficiency effects model have a zero joint influence on the level of technical inefficiency. The findings from Table 3 indicate that this null hypothesis is firmly rejected at the $1 \%$ level of significance, implying that explanatory variables have a significant effect on the variation in the level of technical inefficiency is statistically significant for all group-specific frontier models. With regards to the specification of the function form, the null hypothesis assuming that the Cobb-Douglas production functional form provides a better fit for the data than the translog functional form was accepted for all the group-specific frontiers and the pooled sample.

The fourth test for this study is conducted to examine whether the three groups of farmers (i.e., adopters of hybrid, OPVs, and local maize varieties) share the same production technology. It would not be necessary to estimate the TE relative to a meta-frontier production model if all the individual group frontiers have a common production technology [40]. In particular, the likelihood ratio test of the null hypothesis that all three groups of farmers have the same production technology is computed after estimating the stochastic frontier for the full sample. Findings strongly reject this null hypothesis at the $1 \%$ level of significance, implying that there are significant differences among the three individual group frontiers (i.e., farmers operate under heterogeneous production technologies). Thus, it is necessary to use the meta-frontier approach to estimate and compare the TE levels of maize farms that grow different seed varieties.

The endogeneity test was also performed using the method of Karakaplan, Kutlu [52] which rely on similar ideas with the Durbin and Wu-Hausman test. This test 
Table 3 Results of hypotheses testing

\begin{tabular}{|c|c|c|c|c|c|}
\hline Null hypothesis & LR statistic $(\lambda)$ & Degree of freedom & $p$ value & $\begin{array}{l}\text { Critical value }\left(x^{2},\right. \\
0.05)\end{array}$ & Decision \\
\hline \multicolumn{6}{|l|}{ 1. $H_{0}: \gamma=0$} \\
\hline Local varieties & 6.90 & 1 & 0.007 & 3.84 & Reject $\mathrm{H}_{0}$ \\
\hline OPVs & 9.32 & 1 & 0.000 & 3.84 & Reject $\mathrm{H}_{0}$ \\
\hline Hybrids & 8.65 & 1 & 0.002 & 3.84 & Reject $\mathrm{H}_{0}$ \\
\hline Pooled sample & 10.62 & 1 & 0.001 & 3.84 & Reject $\mathrm{H}_{0}$ \\
\hline \multicolumn{6}{|l|}{ 2. $H_{0}: \delta_{1}=\delta_{2}=\cdots=\delta_{10}=0$} \\
\hline Local varieties & 29.07 & 10 & 0.014 & 18.30 & Reject $\mathrm{H}_{0}$ \\
\hline OPVs & 30.30 & 10 & 0.001 & 18.30 & Reject $\mathrm{H}_{0}$ \\
\hline Hybrids & 28.66 & 10 & 0.022 & 18.30 & Reject $\mathrm{H}_{0}$ \\
\hline Pooled sample & 49.31 & 10 & 0.000 & 18.30 & Reject $\mathrm{H}_{0}$ \\
\hline \multicolumn{6}{|l|}{ 3. $\mathrm{H}_{0}: \beta_{i k}=0$} \\
\hline Local varieties & 5.95 & 10 & 0.306 & 18.30 & Do not reject $\mathrm{H}_{0}$ \\
\hline OPVs & 6.16 & 10 & 0.143 & 18.30 & Do not reject $\mathrm{H}_{0}$ \\
\hline Hybrids & 6.02 & 10 & 0.250 & 18.30 & Do not reject $\mathrm{H}_{0}$ \\
\hline Pooled sample & 6.21 & 10 & 0.515 & 18.30 & Do not reject $\mathrm{H}_{0}$ \\
\hline $\begin{array}{l}\text { 4. All individual groups share the } \\
\text { same technology }\end{array}$ & 61.34 & 37 & 0.008 & 55.75 & Reject $\mathrm{H}_{0}$ \\
\hline \multicolumn{6}{|c|}{ Eta $(\eta)$ endogeneity test $-\left(\chi^{2}=7.12\right)^{a} ; p=0.214$} \\
\hline
\end{tabular}

${ }^{a} \mathrm{H}_{0}$ : No endogeneity in the model, decision: do not reject $\mathrm{H}_{0}$

is typically carried out by testing the joint significance of the components of $\eta$ term $[52,53]$. If $\eta$ is jointly significant, we would confirm the presence of endogeneity in our model. On the other hand, if $\eta$ is not jointly significant, we would conclude that the correction term is not necessary and the efficiency can be estimated using the traditional stochastic frontier models [52-54]. As shown in Table 4, the calculated test statistic is about 7.12 with a greater $\mathrm{p}$ value (0.214), i.e., the components of $\eta$ are not jointly significant, which accept the null hypothesis of no endogeneity in our model. Consequently, the correction term is not necessary and we can estimate the efficiency using the traditional stochastic frontier models.

\section{Estimates of group-specific frontiers}

As explained above in the methodology section, we employ a two-step stochastic meta-frontier approach proposed by Huang et al. [21] to estimate the TE of maize farms that grow different seed varieties. In the first step, group-specific stochastic frontiers are estimated, and the results are presented in Table 4. In this step, the SFA is used to estimate Eqs. (11) and (12). The results given in Table 4 show that for the production function, the coefficients of all variable inputs are statistically significant and have positive signs as expected. Given that we have used the Cobb-Douglas production function, the estimated coefficients of inputs are directly read as the partial production elasticities. For all groups of farmers, the output is most responsive to fertilizer input variable relative to other production input variables (i.e., labor, seed, and land). Notably, the magnitudes of the coefficients are higher (except for labor input variable) for farms growing hybrid maize varieties compared to farms growing OPVs and local maize varieties.

The estimated lambda parameter $(\lambda)$ suggests that there is a presence of technical inefficiency in maize production in all three groups of farmers. ${ }^{3}$ In terms of examining the determinants of technical inefficiency, we present the parameter estimates of relevant variables in Table 4. Variables such as household size and off-farm income are not statistically significant in any of the three groups of farmers. The remaining variables included in the inefficiency effects model appear to be statistically significant, at least in one of the three groups of farmers and have the expected signs. ${ }^{4}$ In particular, education and the availability of extension services have a positive effect on TE for all the farmers' groups, which was expected a priori. Mariano et al. [20] argued that these human capital variables influence farmers' managerial performance. Another interesting finding indicates that membership in farmers'

\footnotetext{
3 The lambda parameter $(\lambda)$ indicates the presence of inefficiency effect with respect to the random noise if it is statistically significant.

4 The negative (positive) sign of a parameter implies that the variable has a positive (negative) effect on TE.
} 
Table 4 Maximum likelihood estimates of group-specific stochastic production frontier model

\begin{tabular}{|c|c|c|c|c|c|c|c|c|c|}
\hline \multirow[t]{2}{*}{ Variable } & \multirow[t]{2}{*}{ Parameter } & \multicolumn{2}{|c|}{ Local varieties } & \multicolumn{2}{|l|}{ OPVs } & \multicolumn{2}{|l|}{ Hybrids } & \multicolumn{2}{|c|}{ Pooled sample } \\
\hline & & Coefficient & std. error & Coefficient & std. error & Coefficient & std. error & Coefficient & std. error \\
\hline \multicolumn{10}{|l|}{ Production frontier } \\
\hline Constant & $\beta_{0}$ & $5.535^{* *}$ & 0.091 & $5.462^{*}$ & 0.126 & $5.637^{* *}$ & 0.118 & $5.610^{* *}$ & 0.094 \\
\hline Inland & $\beta_{1}$ & $0.106^{* *}$ & 0.018 & $0.105^{* * *}$ & 0.006 & $0.113^{* *}$ & 0.011 & $0.105^{* * *}$ & 0.007 \\
\hline Inlabor & $\beta_{2}$ & $0.142^{* * *}$ & 0.024 & $0.171^{* *}$ & 0.017 & $0.168^{* *}$ & 0.019 & $0.156^{* *}$ & 0.020 \\
\hline Infertilizer & $\beta_{3}$ & $0.201^{*}$ & 0.106 & $0.209^{* * *}$ & 0.032 & $0.237^{* * *}$ & 0.021 & $0.206^{* * *}$ & 0.014 \\
\hline Inseed & $\beta_{4}$ & $0.128^{* *}$ & 0.035 & $0.138^{* * *}$ & 0.021 & $0.166^{*}$ & 0.047 & $0.135^{* * *}$ & 0.017 \\
\hline \multicolumn{10}{|c|}{ Socio-economic variables } \\
\hline Constant & $\delta_{0}$ & -2.379 & 0.152 & $-2.794^{* * *}$ & 0.054 & $-2.984^{* *}$ & 0.083 & $-2.781^{* * *}$ & 0.061 \\
\hline Age & $\delta_{1}$ & $0.003^{*}$ & 0.010 & 0.007 & 0.009 & -0.031 & 0.015 & 0.002 & 0.006 \\
\hline Gender & $\delta_{2}$ & $-0.795^{* *}$ & 0.249 & $-0.728^{* * *}$ & 0.233 & $-0.647^{* * *}$ & 0.220 & $-0.737^{* * *}$ & 0.224 \\
\hline Education & $\delta_{3}$ & $-0.151^{* * *}$ & 0.048 & $-0.334^{* *}$ & 0.084 & $-0.428^{*}$ & 0.131 & $-0.237^{* * *}$ & 0.060 \\
\hline Household size & $\delta_{4}$ & -0.068 & 0.065 & -0.032 & 0.052 & 0.074 & 0.214 & -0.035 & 0.057 \\
\hline Coop. membership & $\delta_{5}$ & -0.144 & 0.311 & -0.152 & 0.339 & $-0.313^{*}$ & 0.384 & -0.153 & 0.376 \\
\hline Extension services & $\delta_{6}$ & $-0.135^{*}$ & 0.022 & $-0.021^{* * *}$ & 0.011 & $-0.019^{* *}$ & 0.009 & $-0.027^{* *}$ & 0.013 \\
\hline Credit access & $\delta_{7}$ & 0.192 & 0.047 & $-0.354^{* *}$ & 0.097 & $-0.213^{* * *}$ & 0.030 & $-0.272^{* * *}$ & 0.029 \\
\hline Off- farm income & $\delta_{8}$ & -0.144 & 0.141 & -0.275 & 0.406 & 0.310 & 0.513 & -0.112 & 0.112 \\
\hline Land tenure & $\delta_{9}$ & $-0.326^{* * *}$ & 0.317 & $-0.352^{* *}$ & 0.109 & $-0.285^{* * *}$ & 0.116 & $-0.302^{* *}$ & 0.129 \\
\hline Livestock ownership & $\delta_{10}$ & $-0.801^{* *}$ & 0.123 & $-0.723^{* * *}$ & 0.065 & $-0.476^{* *}$ & 0.155 & $-0.716^{* * *}$ & 0.086 \\
\hline \multicolumn{10}{|l|}{ Model diagnostics } \\
\hline Sigma-u & $\sigma_{u}$ & $0.127^{* * *}$ & 0.011 & $0.132^{* * *}$ & 0.009 & $0.122^{* * *}$ & 0.020 & $0.111^{* * *}$ & 0.013 \\
\hline Sigma $-v$ & $\sigma_{\vee}$ & $0.094^{* * *}$ & 0.013 & $0.079 * * *$ & 0.008 & $0.105^{* *}$ & 0.009 & $0.064^{* * *}$ & 0.006 \\
\hline Variance & $\sigma^{2}$ & $0.025^{* * *}$ & 0.002 & $0.024^{* * *}$ & 0.003 & $0.026^{* *}$ & 0.001 & $0.016^{* * *}$ & 0.002 \\
\hline Lambda & $\lambda$ & $1.351^{* * *}$ & 0.075 & $1.671^{* * *}$ & 0.104 & $1.162^{* * *}$ & 0.022 & $1.718^{* * *}$ & 0.018 \\
\hline Log likelihood function & LLF & -416.351 & & -313.237 & & -504.115 & & -348.808 & \\
\hline No. of observations & & 91 & & 202 & & 67 & & 360 & \\
\hline
\end{tabular}

***, **, and * Statistical significance at the $1 \%, 5 \%$, and $10 \%$ levels, respectively

cooperatives is positively associated with TE for only farmers who planted hybrid maize varieties. A plausible explanation for this finding is that farmers' cooperatives in the study area which are crop-specific, play a significant role in facilitating farmers to get inputs and technical backstopping services during the cropping season. Undoubtedly, these inputs and technical services have direct links with yield and technical efficiency gains, which jointly indicate significant potential for improved smallholder livelihoods [42]. On the other hand, this variable is not statistically significant for farmers who planted OPVs and local maize varieties.

The resource ownership variables such as livestock and land were found to have a significantly positive effect on TE of farmers for all the groups, as expected. Similar findings were also found by Ng'ombe [2] on TE of smallholder maize production in different regions of Zambia. The access to credit also appears to have a positive effect on TE of farmers, except for farmers who planted local maize varieties.

\section{Results of meta-frontier estimation}

To estimate the stochastic meta-frontier production function, we calculated the fitted values for each group, i.e., $\ln \widehat{f}^{j}\left(X_{j i}\right)$ in Eq. (8). The parameter estimates of the stochastic meta-frontier production function are given in Table 5. The results listed in Table 5 indicate that all parameter estimates are statistically significant and have the expected signs. This implies that land, labor, fertilizer, and seed variable inputs play an important role in influencing the technology gap ratio. Concerning the environmental variables, we use the dummy variable for slope, which is equal to 1 if the land is characterized by steep hills and 0 otherwise. As shown in Table 2, the descriptive statistics show that $50 \%$ of farmers in our sample have a sloped land terrain. The slope's significantly positive coefficient implies that the production frontier of farmland, characterized by steep slopes, is likely to be further away from the metafrontier. This finding corroborates the findings of Julien et al. [46], who found a negative relationship between 
Table 5 Parameter estimates of the stochastic metafrontier production function

\begin{tabular}{llll}
\hline Variable & Parameter & Coefficient & Standard error \\
\hline Production frontier & & & \\
$\quad$ Constant & $\beta_{0}$ & $5.343^{* * *}$ & 0.062 \\
InLand & $\beta_{1}$ & $0.127^{* * *}$ & 0.006 \\
InLabor & $\beta_{2}$ & $0.149^{* *}$ & 0.011 \\
InFertilizer & $\beta_{3}$ & $0.252^{* *}$ & 0.007 \\
InSeed & $\beta_{4}$ & $0.139^{* * *}$ & 0.005 \\
Environmental variables & & & \\
Constant & $\delta_{0}$ & $-3.543^{* * *}$ & 0.057 \\
$\quad$ Slope & $\delta_{1}$ & $0.601^{* * *}$ & 0.160 \\
Variance parameters & & & \\
Sigma-u & $\sigma_{u}$ & $0.124^{* * *}$ & 0.046 \\
Sigma-V & $\sigma_{V}$ & $0.025^{* * *}$ & 0.003 \\
Variance & $\sigma^{2}$ & $0.016^{* * *}$ & 0.005 \\
Lambda & $\lambda$ & $4.961^{* * *}$ & 0.009 \\
Log likelihood function & & -677.523 & \\
Total number of observation & 360 & \\
\hline
\end{tabular}

$* * *, * *$, and ${ }^{*}$ Statistical significance at $1 \%, 5 \%$, and $10 \%$ levels, respectively

Table 6 Summary statistics of various measures of TE for maize farmers

\begin{tabular}{lllll}
\hline Range of TE (\%) & Mean & Std. dev & Minimum & Maximum \\
\hline Local varieties & & & & \\
Group-specific TE & 0.592 & 0.052 & 0.360 & 0.674 \\
Meta-frontier TE & 0.483 & 0.044 & 0.357 & 0.809 \\
TGR & 0.615 & 0.035 & 0.488 & 0.811 \\
OPVs & & & & \\
Group-specific TE & 0.670 & 0.040 & 0.376 & 0.835 \\
Meta-frontier TE & 0.594 & 0.039 & 0.365 & 0.864 \\
TGR & 0.752 & 0.032 & 0.523 & 0.870 \\
Hybrids & & & & \\
Group-specific TE & 0.718 & 0.033 & 0.403 & 0.896 \\
Meta-frontier TE & 0.651 & 0.040 & 0.348 & 0.877 \\
TGR & 0.801 & 0.028 & 0.590 & 0.901 \\
Pooled sample & & & & \\
Group-specific TE & 0.663 & 0.039 & 0.360 & 0.896 \\
Meta-frontier TE & 0.580 & 0.047 & 0.348 & 0.877 \\
TGR & 0.728 & 0.031 & 0.488 & 0.901 \\
\hline
\end{tabular}

slope and farm performance (i.e., technical efficiency) in Malawi, Tanzania, and Uganda.

\section{Estimation and comparison of technical efficiency levels}

The estimates of TE scores with respect to the group frontiers, the MTE, and the TGR are presented in Table 6. In terms of the measures of TE relative to the group-specific production frontiers, the results given in Table 6 indicate that farms growing hybrid maize varieties appear to have a higher level of TE $(71.8 \%)$ than farms growing OPVs (67\%) and local maize varieties (59.2\%). However, these estimates cannot be used to compare the managerial performance (i.e., technical efficiency) of maize farmers in three individual groups using different maize varieties. In "Model specification tests" section above, we demonstrated that there are significant differences among the three individual group frontiers (i.e., farmers operate under heterogeneous production technologies). Thus, it is necessary to use the meta-frontier approach to compare the managerial performance of maize farmers who grow different maize varieties. In this regard, we used the MTE and TGR estimates obtained from the specification of Eqs. (4) and (6).

The results listed in Table 6 show that the mean TGR of farms growing hybrid maize varieties $(80.1 \%)$ is higher than the mean TGR of farms growing OPVs (75.2\%) and local maize varieties (61.5\%). This implies that, on average, farms growing hybrid maize varieties produce about $80.1 \%$ of the maximum output that can be obtained using the available production technology in Rwanda. Farms growing OPVs produce roughly $75.2 \%$ of the potential output. On the other hand, farms growing local maize varieties produce approximately $61.5 \%$ of the possible output given the available production technology in Rwanda. The difference in mean TGRs between adopters of hybrids and local seeds is statistically significant at $5 \%$ ( $\mathrm{t}$ value $=132.814)$. These results imply that farms growing hybrid maize varieties performs better than farms growing OPVs and local maize varieties. Villano et al. [29] noted a significant gaps in managerial performance of farmers using different seed varieties in rice production in the Philippines.

Regarding the estimated MTE values, the results given in Table 6 show that farms growing hybrid maize varieties recorded the highest mean TE score for the metafrontier function $(65.1 \%)$ followed by farms growing OPVs (59.4\%). Farms growing local maize varieties have the lowest mean TE score relative to the meta-frontier function (48.3\%). Generally, we note that there are significant differences in the mean values of TE, TGR, and MTE across the three individual group frontiers, indicating the gaps in managerial performance among farmers.

\section{Conclusion and policy implications}

Rwanda and most parts of sub-Saharan Africa face severe challenges of increasing maize productivity, which has direct consequences on food security. These challenges have led to public policies focusing on finding the costeffective strategies of boosting maize production. In this study, we applied the stochastic meta-frontier approach to estimate and compare the TE and technology gaps of 
maize farms that grow different seed varieties in Rwanda. Data were obtained from a household survey carried out in Rwanda during the 2018-2019 cropping season. The sample size is about 360 household farmers who were randomly selected from three districts of the Eastern Province of Rwanda. The hypothesis tests confirmed that maize farmers in our sample operate under heterogeneous production technologies. This result justifies the need to use the meta-frontier approach to estimate and compare the TE levels of maize farms that grow different seed varieties.

Our results also show the significant role of variables such as land, labor, fertilizer, and seed in influencing the TE and technology gap ratio. Regarding the factors that determine the inefficient component, we find that education and extension services have a positive effect on TE for all the farmers' groups, which, as expected. Membership in farmers' cooperatives also has a positive impact on TE for farmers who planted hybrid maize varieties. These findings suggest that policies aiming to enhance the level of TE and productivity should focus on expanding the delivery of extension services and strengthening the technical assistance provided to farmers' cooperatives. The TE measures obtained from both the groupspecific frontiers and the meta-frontier indicate that maize farms in all groups operate below the frontier, which implies a scope to achieve the maximum potential output possible using the current level of inputs and technology.

The results obtained from the meta-frontier estimation confirm significant differences in the mean values TE, TGR, and MTE across the three individual group frontiers, indicating the gaps in managerial performance among farmers. From a policy perspective, these findings suggest the development of policy measures that may reduce the managerial and technological gaps existing among farmers to improve productivity and food security. Based on the results of this study, one of the crucial avenues to close this gap would be to improve access to improved agricultural technologies such as improved hybrid seeds. Finally, given that this study is the first to examine the relative TE of farms operating under different production technologies in Rwanda, we admit some limitations are worth mentioning. Future research should consider using panel data to provide results of more excellent value. Moreover, studies covering various crops and more conventional inputs are worthy of future research.

\section{Abbreviations}

CIP: Crop intensification program; DAP: Di-ammonium phosphate; DEA: Data envelopment analysis; Ha: Hectares; IMVs: Improved maize varieties; Kg: Kilograms; MINAGRI: Ministry of Agriculture and Animal Resources; MLE:
Maximum likelihood estimation; MT: Metric ton; OPVs: Open-pollinated varieties; SFA: Stochastic frontier analysis; SMF: Stochastic meta-frontier; SSA: Sub-Saharan Africa; TE: Technical efficiency; TGRs: Technology gap ratios; TLU: Tropical livestock units.

\section{Acknowledgements}

This study is a part of the Doctoral thesis by the first author. We thank the government of the Republic of Korea through the Korean Government Scholarship Program (KGSP) for sponsoring this PhD program. We would like also to thank Papias Mucyo and Claude Migambi of the Rwanda Agriculture Board for their assistance with data collection. The authors also thank two anonymous reviewers and the Editor-in-Chief, Fabio Santeramo for their valuable comments and suggestions.

\section{Authors' contributions}

J.N. conceived the idea for this research and was responsible for designing the study and data collection. J.N. was responsible for data analysis and original draft preparation. S.J.H. supervised, provided technical advice in formulation of the research objectives, and reviewed the manuscript. All authors read and approved the final manuscript.

\section{Funding}

No funding was received for this research study.

\section{Availability of data and materials}

Data used for this study will be made available from the corresponding author on request.

Ethics approval and consent to participate

Not applicable since the study involved maize crop.

\section{Consent for publication}

Not applicable.

\section{Competing interests}

We declare that this research study has no potential competing interests.

Received: 2 July 2020 Accepted: 28 December 2020

Published online: 19 April 2021

\section{References}

1. Ogundari KA, meta-regression analysis of frontier efficiency estimates from Africa. . Agricultural and Applied Economics Association Annual Meeting. Minnesota: Minneapolis; 2014. p. 1659112014.

2. Ngombe JN. Technical efficiency of smallholder maize production in Zambia: a stochastic meta-frontier approach. Agrekon. 2017:56(4):347-65. https://doi.org/10.1080/03031853.2017.1409127.

3. Khanal U, Wilson C, Shankar S, Hoang VN, Lee B. Farm performance analysis: Technical efficiencies and technology gaps of Nepalese farmers in different agro-ecological regions. Land Use Policy. 2017;2018(76):645-53. https://doi.org/10.1016/j.landusepol.2018.02.045.

4. Mariano MJ, Villano R, Fleming E. Technical efficiency of rice farms in different agroclimatic zones in the Philippines: an application of a stochastic metafrontier model. Asian Econ J. 2011;25(3):245-69. https://doi.org/10.1 111/j.1467-8381.2011.02060.x

5. Mariko K, Macalou M, Xiangmei L, Matafwali E, Alavo JPE, Eltom EA, et al. Stochastic meta frontier analysis of smallholder rice farmers' technical efficiency. J Agric Sci. 2019;11(8):31-44. https://doi.org/10.5539/jas.v11n8 p31.

6. Melo-Becerra LA, Orozco-Gallo AJ. Technical efficiency for Colombian small crop and livestock farmers: A stochastic metafrontier approach for different production systems. J Prod Anal. 2017;47(1):1-16. https://doi. org/10.1007/s11123-016-0487-x.

7. Onumah JA, Onumah EE, Al-Hassan RM, Brümmer B. Meta-frontier analysis of organic and conventional cocoa production in Ghana. Agric Econ. 2013;59(6):271-80. https://doi.org/10.17221/128/2012-agricecon. 
8. Santeramo FG. On the composite indicators for food security: decisions matter! Food Rev Int. 2015;31(1):63-73. https://doi.org/10.1080/87559 129.2014.961076.

9. Timmer CP. The macro dimensions of food security: economic growth, equitable distribution, and food price stability. Food Policy. 2000;25(3):283-95. https://doi.org/10.1016/S0306-9192(00)00007-5.

10. Gross $\mathrm{R}$, Schoeneberger $\mathrm{H}$, Pfeifer $\mathrm{H}$, Preuss $\mathrm{H}$-J. The four dimensions of food and nutrition security: definitions and concepts. SCN News. 2000;20(20):20-5.

11. Minagri. Strategic Plan for the Transformation of Agriculture in RwandaPhase IV: 2018-2024. Ministry of Agriculture and Animal Resources (MINAGRI), Kigali, Rwanda. 2018.

12. Ngango J, Kim GS. Assessment of technical efficiency and its potential determinants among small-scale coffee farmers in Rwanda. Agriculture. 2019;9(7):161. https://doi.org/10.3390/agriculture9070161.

13. Kathiresan A. Strategies for Sustainable Crop Intensification in Rwanda. Shifting focus from producing enough to producing surplus. 2011. p. $1-59$.

14. Matsiko F, Kanyange C, Ingabire G, Dusingizimana T, Vasanthakaalam $\mathrm{H}$, Kimonyo A. Detection and quantification of aflatoxin in cassava and maize flour sold in Kigali open markets. Rwanda Int Food Res J. 2017;24(1):459-64.

15. Nahayo A, Omondi MO, Zhang X, Li L, Pan G, Joseph S. Factors influencing farmers' participation in crop intensification program in Rwanda. J Integr Agric. 2017;16(6):1406-16. https://doi.org/10.1016/S2095-3119(16)61555 -1 .

16. Karangwa M. The effect of land fragmentation on the productivity and technical efficiency of smallholder maize farms in southern Rwanda. 2010.

17. Mulinga N. Economic analysis of factors affecting technical efficiency of smallholders maize production on Rwanda. Rwanda J. 2013;1(1):52-62. https://doi.org/10.4314/rj.v1i1.4H.

18. Ngabitsinze JC. Analysis of economic efficiency of maize production in Huye District in Rwanda. Int J Agric Innov Res. 2014;3(3):707-16.

19. Jiang N, Sharp B. Technical efficiency and technological gap of New Zealand dairy farms: a stochastic meta-frontier model. J Prod Anal. 2015;44(1):39-49. https://doi.org/10.1007/s11123-015-0429-z.

20. Mariano MJ, Villano R, Fleming E. Are irrigated farming ecosystems more productive than rainfed farming systems in rice production in the Philippines? Agric Ecosyst Environ. 2010;139(4):603-10. https://doi. org/10.1016/j.agee.2010.10.004.

21. Huang $\mathrm{CJ}$, Huang $\mathrm{T}-\mathrm{H}$, Liu N-H. A new approach to estimating the metafrontier production function based on a stochastic frontier framework. J Prod Anal. 2014;42(3):241-54. https://doi.org/10.1007/s11123-014-0402-2.

22. Chang BG, Huang TH, Kuo CY. A comparison of the technical efficiency of accounting firms among the US, China, and Taiwan under the framework of a stochastic metafrontier production function. J Prod Anal. 2015;44(3):337-49. https://doi.org/10.1007/s11123-014-0397-8.

23. Ansoms A, Cioffo G, Dawson N, Desiere S, Huggins C, Leegwater M, et al. The Rwandan agrarian and land sector modernisation: confronting macro performance with lived experiences on the ground. Rev Afr Polit Econ. 2018;45(157):408-31. https://doi.org/10.1080/03056244.2018.14975 90.

24. Bizoza AR. Institutions and the adoption of technologies: Bench Terraces in Rwanda. In: Vanlauwe B, van Asten P, Blomme G, editors. Challenges and opportunities for agricultural intensification of the humid highland systems of sub-Saharan Africa. Cham: Springer; 2014. p. 335-54.

25. McMillan M, Headey D. Introduction-understanding structural transformation in Africa. World Dev. 2014;63:1-10. https://doi.org/10.1016/j.world dev.2014.02.007.

26. Ali DA, Deininger $\mathrm{K}$. Is there a farm size-productivity relationship in African agriculture? Evid Rwanda Land Econ. 2015;91(2):317-43. https://doi. org/10.3368/le.91.2.317.

27. Ntihinyurwa PD, de Vries WT, Chigbu UE, Dukwiyimpuhwe PA. The positive impacts of farm land fragmentation in Rwanda. Land Use Policy. 2019;81:565-81. https://doi.org/10.1016/j.landusepol.2018.11.005.

28. Ansoms A, Verdoodt A, Van Ranst E. The inverse relationship between farm size and productivity in rural Rwanda. Universiteit Antwerpen, Institute of Development Policy (IOB). 2008.

29. Villano R, Bravo-Ureta B, Solís D, Fleming E. Modern rice technologies and productivity in The Philippines: Disentangling technology from managerial gaps. J Agric Econ. 2015;66(1):129-54. https://doi. org/10.1111/1477-9552.12081.

30. Becerril J, Abdulai A. The impact of improved maize varieties on poverty in Mexico: A propensity score-matching approach. World Dev. 2010;38(7):1024-35. https://doi.org/10.1016/j.worlddev.2009.11.017.

31. Manda J, Gardebroek C, Kuntashula E, Alene AD. Impact of improved maize varieties on food security in Eastern Zambia: a doubly robust analysis. Rev Dev Econ. 2018;22(4):1709-28. https://doi.org/10.1111/ rode. 12516.

32. Ndoli A, Baudron F, Sida TS, Schut AGT, Van Heerwaarden J, Giller KENE. Do open-pollinated maize varieties perform better than hybrids in agroforestry systems? Exp Agric. 2019;55(4):649-61. https://doi.org/10.1017/ S0014479718000297.

33. Boshrabadi HM, Villano R, Fleming E. Technical efficiency and environmental-technological gaps in wheat production in Kerman province of Iran. Agric Econ. 2008;38(1):67-76. https://doi.org/10.111 1/j.1574-0862.2007.00282.x.

34. Aigner D, Lovell CAK, Schmidt P. Formulation and estimation of stochastic frontier production function models. J Econometr. 1977;6(1):21-37. https ://doi.org/10.1016/0304-4076(77)90052-5.

35. Meeusen W, van Den Broeck J. Efficiency estimation from Cobb-Douglas production functions with composed error. Int Econ Rev. 1977;18(2):43544. https://doi.org/10.2307/2525757.

36. Liu W. Regional technical efficiency and technology gaps in rural China: evidence from CHIP surveys. China Econ J. 2012;4(2-3):125-44. https:// doi.org/10.1080/17538963.2011.666058.

37. Hayami Y. Sources of agricultural productivity gap among selected Countries. Am J Agric Econ. 1969;51(3):564-75. https://doi.org/10.2307/12379 09.

38. Hayami Y, Ruttan VW. Agricultural productivity differences among countries. Am Econ Rev. 1970;60(5):895-911.

39. Battese GE, Rao DSP. Technology gap, efficiency, and a stochastic metafrontier function. Int J Busin Econ. 2002;1 (2):87-93.

40. Battese GE, Prasada Rao DS, O'Donnell CJ. A metafrontier production function for estimation of technical efficiencies and technology gaps for firms operating under different technologies. J Prod Anal. 2004;21(1):91103. https://doi.org/10.1023/B:PROD.0000012454.06094.29.

41. O'Donnell CJ, Rao DSP, Battese GE. Metafrontier frameworks for the study of firm-level efficiencies and technology ratios. Empir Econ. 2008;34(2):231-55. https://doi.org/10.1007/s00181-007-0119-4.

42. Abdul-Rahaman A, Abdulai A. Do farmer groups impact on farm yield and efficiency of smallholder farmers? Evidence from rice farmers in northern Ghana. Food Policy. 2018;81:95-105. https://doi.org/10.1016/j. foodpol.2018.10.007.

43. Battese GE, Coelli TJ. A model for technical inefficiency effects in a stochastic frontier production function for panel data. Empir Econ. 1995;20(2):325-32. https://doi.org/10.1007/BF01205442.

44. Zeweld W, Huylenbroeck GV, Hidgot A, Chandrakanth MG, Speelman S. Adoption of small-scale irrigation and its livelihood impacts in Northern Ethiopia. Irrig Drain. 2015;64(5):655-68. https://doi.org/10.1002/ird.1938.

45. Khataza RRB, Hailu A, Kragt ME, Doole GJ. Estimating shadow price for symbiotic nitrogen and technical efficiency for legume-based conservation agriculture in Malawi. Aust J Agric Resour Econ. 2017;61(3):462-80. https://doi.org/10.1111/1467-8489.12212.

46. Julien JC, Bravo-Ureta BE, Rada NE. Assessing farm performance by size in Malawi, Tanzania, and Uganda. Food Policy. 2019;84:153-64. https://doi. org/10.1016/j.foodpol.2018.03.016.

47. Anang BT, Bäckman S, Rezitis A. Production technology and technical efficiency: irrigated and rain-fed rice farms in northern Ghana. Eur Econ Rev. 2017;7(1):95-113. https://doi.org/10.1007/s40822-016-0060-y.

48. Helfand SM, Levine ES. Farm size and the determinants of productive efficiency in the Brazilian Center-West. Agric Econ. 2004;31(2-3):241-9. https://doi.org/10.1111/j.1574-0862.2004.tb00261.x.

49. Mar S, Nomura H, Takahashi Y, Ogata K, Yabe M. Impact of erratic rainfall from climate change on pulse production efficiency in Lower Myanmar. Sustainability. 2018;10(2):402. https://doi.org/10.3390/su10020402.

50. Mwalupaso GE, Wang S, Rahman S, Alavo EJP, Tian X. Agricultural informatization and technical efficiency in maize production in Zambia. Sustainability. 2019;11(8):2451. https://doi.org/10.3390/su11082451.

51. Xin X, Zhang Y, Wang J, Nuetah JA. Effects of Farm Size on Technical Efficiency in China's Broiler Sector: A Stochastic Meta-Frontier Approach. 
Canad J Agric Econ. 2016;64(3):493-516. https://doi.org/10.1111/ cjag.12093.

52. Karakaplan M, Kutlu L. Handling endogeneity in stochastic frontier analysis. 2015.

53. Karakaplan MU, Kutlu L. Handling endogeneity in stochastic frontier analysis". Econ Bull. 2017;37(2):889-901.

54. Karakaplan MU, Kutlu L. Endogeneity in panel stochastic frontier models: an application to the Japanese cotton spinning industry. Appl Econ. 2017;49(59):5935-9. https://doi.org/10.1080/00036846.2017.1363861.

\section{Publisher's Note}

Springer Nature remains neutral with regard to jurisdictional claims in published maps and institutional affiliations.
Ready to submit your research? Choose BMC and benefit from:

- fast, convenient online submission

- thorough peer review by experienced researchers in your field

- rapid publication on acceptance

- support for research data, including large and complex data types

- gold Open Access which fosters wider collaboration and increased citations

- maximum visibility for your research: over 100M website views per year

At BMC, research is always in progress.

Learn more biomedcentral.com/submissions 